\title{
Reconsider deschooling: Alternative towards more accessible and inclusive education
}

\section{Mempertimbangkan kembali deschooling: Alternatif menuju pendidikan lebih terakses dan inklusif}

\author{
$\underline{\text { Agie Nugroho Soegiono }}^{1}$, Aulia Anis $^{2}$ \& Saskia Rizqina Maulida ${ }^{1}$ \\ ${ }^{1}$ Faculty of Social and Political Sciences, Universitas Airlangga \\ ${ }^{2}$ Institute of Social Sciences, Sakarya Üniversitesi \\ Address: ${ }^{1}$ Jalan Dharmawangsa Dalam, Surabaya, East Java 60286 \\ ${ }^{2}$ Kemalpaşa Mahallesi, Üniversite Cd. Esentepe Kampüsü, 54050 Serdivan/Sakarya, Turkey \\ E-mail: agiesoegiono@fisip.unair.ac.id; aulia.anis@ogr.sakarya.edu.tr \& \\ saskia.rizqina.maulida-2017@fisip.unair.ac.id
}

\begin{abstract}
This essay discusses deschooling concept as an alternative learning delivery method to achieve education for all. We argue that the deschooling idea, first introduced by Illich before the era of the Internet, has become relevant in relation to today's education challenges. What we mean by deschooling in this paper is not the abolishment of the schooling system. Instead, the recall of deschooling discourse aims to provide more recognition of learning activities outside of the school setting. The learning webs, a key enabler in deschooling discourse, are realistic when implemented with the help of $21^{\text {st }}$ century's technology. The argument in this paper utilised an in-depth literature review and discourse analysis in the deschooling debate. To strengthen our argument, we have provided three case studies in the form of informal learning, non-formal learning and e-learning related to deschooling initiatives. Based on our findings, we can conclude that deschooling society is certainly viable. The principles used in deschooling, such as flexibility, inclusiveness, adaptability and personalisation, are alternatives for everyone to have freedom of access, use, copy, and modify learning resources. We also found that there may be possible challenges, including the limitation of self-directed learning, the pitfall of institutionalised capital and a lack of social interaction.
\end{abstract}

Keywords: education for all; deschooling; open science; informal school; non-formal school; e-learning; institutionalism; inclusive education

\begin{abstract}
Abstrak
Esai ini mendiskusikan konsep deschooling sebagai alternatif dalam upaya mencapai pendidikan untuk semua. Kami menilai konsep deschooling yang digagas oleh Illich di era sebelum internet layak kembali untuk didiskusikan. Perlu dicatat bahwa deschooling yang kami gunakan sebagai landasan teori bukanlah untuk meniadakan sistem sekolah, namun sebagai gagasan untuk memberikan rekognisi kepada lingkungan pembelajaran di luar sekolah formal. Salah satu aspek dalam gagasan deschooling adalah learning webs yang sangat realistik untuk diimplementasikan dengan bantuan teknologi abad 21. Penjabaran argumen pada studi ini diolah melalui serangkaian studi literatur dan analisis diskursus mendalam pada pembahasan deschooling. Untuk memperkuat argumen, kami menyediakan tiga studi kasus terkait inisiatif deschooling di Indonesia dalam bentuk pembelajaran informal, pembelajaran non-formal dan pembelajaran elektronik. Kami menyimpulkan bahwa konsep deschooling sangat mungkin untuk dilaksanakan. Prinsip-prinsip yang digunakan dalam deschooling seperti fleksibilitas, inklusivitas, kemampuan adaptasi dan personalisasi adalah hal-hal yang dapat memberikan setiap orang kebebasan untuk dapat mengakses, menggunakan, memperbanyak, dan memodifikasi sumber pembelajaran. Kami juga menemukan adanya tantangan yang mungkin muncul dalam realisasi deschooling, yaitu limitasi dari pembelajaran mandiri, kelemahan dari kapital yang dilembagakan dan kurangnya interaksi sosial.
\end{abstract}

Kata kunci: pendidikan untuk semua; deschooling; sains terbuka; sekolah informal; sekolah non-formal; pembelajaran elektronik; institusionalisme; pendidikan inklusif 


\section{Introduction}

History writes that there have always been political issues that prevent disadvantaged and minority groups from obtaining their rights associated with education. Issues in relation to education barriers vary from race to caste, gender to sexual interest or groups with special needs to low-economic groups. While there are numerous dimensions used to highlight education achievements in a community, commonly, educational progress is measured by measuring children's participation at school. Since its first appearance 300 years ago, school has been primarily considered as a major part of achieving education for all (Bartling \& Friesike 2014). The mass invention of the school establishment marked the first scientific revolution that took place during Europe's industrial period and this has continued since.

The signification of school as the primary learning service provider denotes the institutionalisation of education. Institutionalisation often frames the propensity of community reliance on a particular institution as the primary service delivery (Kominek 2009). For this situation, school appears to have become the only dominant place delivering education. This dominant substance subsequently monopolises the recognition of learning. Any individual whose learning achievement wishes to be recognised must follow the system, leading to a universal premise of 'education is about schooling' or 'education should be at school'. Two and a half-century later, we are still desperately looking for ways to provide education to poor communities that might answer problems such as inequality, poverty, and injustice in society.

The dependence on institutionalised education is vigorously followed by today's governments in the world, directing a global political strategy to widen educational services. A global mission called 'Education for All' was firstly introduced in the 2000 Dakar conference to ensure everyone has the same chance to obtain basic education by 2015. However, a global report in 2014 recognised that the objective has not yet been accomplished (UNESCO 2014). There is still a high number of marginalised people in many parts of the globe who are still deprived of access to education.

The unsatisfied result of Dakar's Education For All leads to criticism which addresses the inefficiency of the education budget that relies too much on investing in school infrastructure and curricula (Zaldívar 2015:94). Zaldivar argues that instead of addressing the unachievable school establishment, the world should address quality learning as a major issue in order to improve the lives of the community. The idea to address more attention on quality learning was then positively received by the World Bank, which proposed a core change from 'Education for All' into 'Learning for All' as the key aspect for further development (World Bank Group 2011). The report suggested that the global commitment to improving learning development should 'look beyond schooling'. Interestingly, the idea to look beyond schooling is not a new discourse, if we relook at 'Deschooling Society', a thought previously proposed by education critic, Ivan Illich, in the 1970s.

This essay will discuss the search for education alternatives by readdressing the thoughts of Ivan Illich on deschooling. The question of this research is to what extent the deschooling concept can be an alternative method to deliver education, especially in the context of providing the learning environment? What are the possible challenges for actualising the deschooling initiatives? We argue that the significance of Illich's deschooling is appropriate enough to be re-discussed in today's global education situation, where marginalised communities still endlessly faces unequal access to education. To answer this question, we have highlighted a case study of education delivery in Indonesia, where the education service provider has been dealing with geographical problems, a lack of infrastructure, and insufficient human resources.

The structure of this essay will be divided into several parts. The first part will emphasise deschooling as part of a general discussion followed by stating the urgency of providing an alternative learning environment. We have pointed out the distinct learning characteristics in a deschooling environment where the institutionalised procedure used is needless. The second part will be dedicated to Illich's idea of learning webs, which is a strategy of his deschooling propaganda that seems realistic to 
implement with the help of $21^{\text {st }}$-century technologies. Lastly, three examples of education initiatives in Indonesia will be displayed in order to depict some of the best practices in relation to realising deschooling.

\section{Research Method}

This research was mainly conducted by using a literature review and discourse analysis to analyse the hegemony problem of institutionalised education and thereafter, suggesting several alternatives that are non-school education services. Regarding the literature of this research, we studied 75 published texts which then were narrowed down to 15 relatable texts. In order to retrieve the related articles, five research engines were used; Google Scholar, Mendeley, Taylor Francis, Sage Publication and Science Direct.

Discourse analysis was also used to define the causal effect of the context written in the articles (Fairclough 2003). In this research, the text was categorised as parts of the article were found to support the analysis of the phrases and keywords chosen. For this reason, the usage of several keywords in the searching engines such as 'deschooling', 'inclusive education', 'informal learning', 'non-formal learning', 'open science', 'e-learning' and 'education for all' were beneficial to limit the context of the research. However, this research did not conduct an empirical study. Therefore, we suggest that a study should be conducted with direct observations and fieldwork on one of the deschooling initiatives as future research.

The locus of this research was Indonesia. The reason for choosing Indonesia is based on its education delivery journey, where the geographic problems, lack of infrastructure and inadequate human resources remain barriers to achieving education for all. During the exploration of alternative education in Indonesia, we have found three interesting case studies that we would like to address. These initiatives are informal learning (Sokola Rimba), non-formal learning (Pesantren and Kampung Inggris), and e-learning (Buku Sekolah Digital and IndonesiaX). The decision to select Sokola Rimba as our case study is based on the positive media coverage, international recognition in the form of awards, and its location where school or any other infrastructure does not even exist. Pesantren and Kampung Inggris are discussed because of their learning delivery that differs from the national education system, curriculum, and pedagogy. For Buku Sekolah Digital and IndonesiaX, both offer education delivery through the use of technology for distance learning and provide free access to learning contents.

It is important to note that what we mean by deschooling is not the abolishment of schools and going fully informal. In this research, we point out that deschooling is a reduction effort focused on the institutionalism and school hegemony in education, while at the same time, giving more recognition to those who learn outside of school.

\section{Results and Discussion}

\section{The discourse of deschooling and its critique of school hegemony}

The deschooling concept was first introduced by Austrian philosopher, Ivan Illich (1926-2002), who lived in the era before the internet. His radical challenge was based on the view that 'education is all about learning, not merely about schooling'. Illich's thoughts were seen of as a response to the out-of-control commercialisation in education. Illich saw schooling as a commodity of non-material needs. Schooling created a hegemony where relevant learning instruction happens only within the school rather than addressing humans as a casual learner that masters skills and/or lessons naturally from learning activities (Illich 1971:11). Illich's critique of the dominant framework of educational institutionalisation was in line with Apple's thoughts on school hegemony. In Apple's view, school is an absolute cultural and political hegemony that creates a circumstance where no one sees any possibility to gain knowledge outside of a recognised institution such as a school (Apple 2012:4).

While some scholars tend to see Illich's thought of deinstitutionalising schools as a utopia, Routray 
was more concerned with Illich's effort to reduce the central technocrat's power in education. The strong political power of the school hegemony will result in a form of standardisation in education. A higher standard is implemented when educational services become more competitive. Routray saw that this continuous increase of standardisation in school would divide society into discrete classes which struggle to survive and compete in the modern industrial world (Routray 2012:86). As a result, the exclusion of marginalised groups cannot be avoided following the disadvantageous that they gain because the education service is delivered equally but not equitably. In order to provide a better understanding of Illich's critiques on schooling, Figure 1 is displayed below to depict the vicious circle of the strong influence on school hegemony visually.

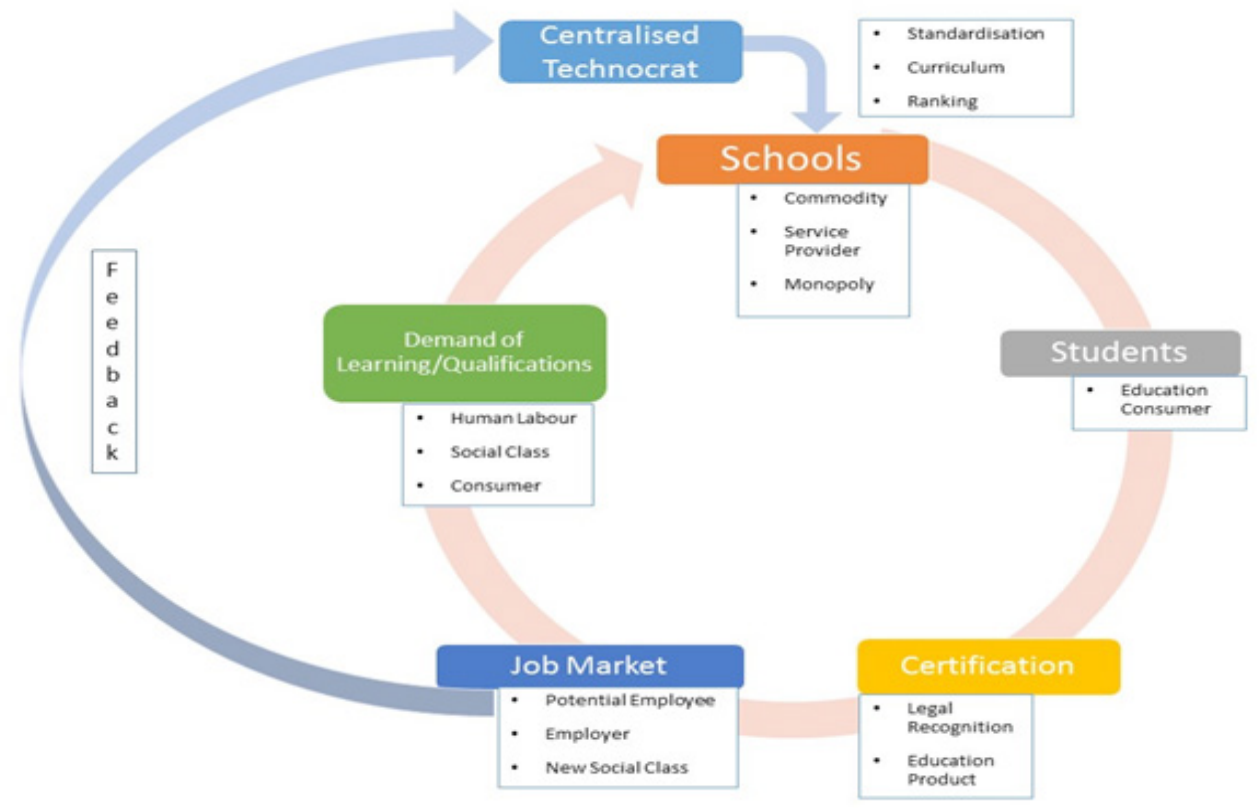

Figure 1.

Vicious circle in schooling

Source: Author's elaboration

First, as the competition takes place in the job market, the demand for acquiring particular skills and qualifications increases. In order to compete, education and training services become valuable for labour forces to participate in. The quality of a person is determined by the training time and educational level engaged in. Those who finish a certain level of education will acquire recognition from technocrats in the forms of degree. The higher the educational level, the broader the job market is that educated individuals can enter. However, while we agree that formal education could become a social climb for individuals, formal education also widely divides the community into different classes. These distinctive classes vary from those who go to school and those do not, those who finish school and those do not, and those who can afford schooling and those who cannot. This was seen by Illich as 'social polarisation'; a consequence of education. Even within schools, the social gap can possibly widen. For example, if the government's expenditure for free schooling is cut, this would result in a rise in the dropout number of poor community groups. Meanwhile, the middle to high-class groups will affected by the policy.

The relationship between polarisation and institutionalisation was also explained in Pierre Bourdieu's The Forms of Capital (1986). Besides a person's status, which is symbolically embodied in his social environment, Bourdieu argues that cultural capital could also be identified by recognising the objectified belongings which a person owns (Bourdieu 1986). In a school context, some students may own more books, gadgets, or other supplementary learning materials compared to poor student groups. If there is no effort from the school committee to facilitate mutual access to learning materials, different outcomes may take place. A person who has more objectified capital is likely to be more productive. Thus, we argue that capital is one of the essential factors that determine someone's education success. 
As a school is the only accredited institution that can officially release certification of learning achievements, it can be said that school constitutes a hegemony of recognised values. For example, a degree license. A degree license is often deified as an objectified product in determining someone's capacity and capability level. In modern society, the assumption that 'a degree will guarantee a better social recognition' is strong and supported by exclusive administrative procedures. We point out here that official recognition from institutions could promote social regression. For instance, any non-recognised individual (uncertified persons) will find it hard to be accepted in a competitive job market. Furthermore, the non-recognised individual may probably be discredited by institutions, regardless of his or her length of time involved in the (informal/non-institutionalised) learning process. Therefore, in the form of academic qualifications, institutionalised recognition is another form of cultural capital, which can strongly determine the cultural identity embodied within a person.

Following the increased number of graduates of a certain level, it is possible that the demand for higher qualification will escalate. In this new but more competitive job market, a certain qualification which was once highly recognised can be considered no longer viable. This was what Schofer and Meyer (2005:900-902) saw of as a 'fear of over education'. The expansion in the number of highly educated workers will potentially result in an increase in unemployment, which eventually causes the misdistribution of the mixture between anomic and unemployed educated workers and elites (Fraser 2000:111). As a result, those who want to pursue higher recognition should consider undertaking yet more training and further schooling, ensuring that they return to the pathway of the school circle. Finally, inequalities increase not only within the certified and educated elite but they also spread more widely, leaving those who are uneducated even further behind.

\section{Learning webs and their possibility in the $21^{\text {st }}$ century}

One interesting idea that came from Illich's deschooling society was the proposal of learning webs. Before the internet was invented, learning webs was an environmental platform for self-driven studying habits. In the learning web environment, studying was conducted to undertake and create skill models related to the individual's interests. Illich proposed that the only thing that should be institutionalised would be the so-called "bank for skill exchange". Bank for skill exchange referred to an open repository that enables individuals to gain access to educational materials. With the help of today's technologies, bank for skill exchange realisation could be possible.

Before we address the connection between learning webs and today's internet of things, it is better for us to highlight the education purposes that Illich wanted to address. In its original version, Illich argues that a sufficient education system should be prepared to deliver three purposes. Firstly, education that provides access to educational sources containing any knowledge for individuals to find and use to explore their interests. Secondly, an environment of education which means that individuals can share their knowledge with other individuals. Thirdly, a mechanism which allows individuals to present important issues to the public. Connecting to Bartling and Friesike' thesis, what Illich wanted to strengthen was knowledge creation and dissemination, two key factors that have influence scientific revolutions throughout human history (Bartling \& Friesike 2014). We summarise that Illich's intention was to create an open, free, and independent learning circumstance, a learning environment without any discrimination or institutionalised restricted requirements in order to achieve inclusive education.

Learning webs that consist of reference services to educational objects, mechanisms of skill exchange and peer-matching, as well as education hearings at large, seem identical to address today's internet of things era where pro-open academics support the establishment of open science. Open science is an effort to make the world of sciences be more reachable and inclusive through the usage of information and communication technology (ICT). Illich, Morgan, Barling, and Friesike all agree that institutionalised education could lead to education being a commodity that prevents disadvantaged communities from gaining adequate education access. However, this could be minimised by transforming the educational materials that are collected into an online repository without restricted access. ICT's influences in education do not finish only in relation to online repository establishment. 
In the $21^{\text {st }}$ century, more innovations are born in various innovative forms such as flexible-learning in the open community, the free choice of courses, open educational resources (OER), and massive open online courses (MOOC). All of these new platforms do not only widen educational materials to any user, but they also strengthen more human interactions which stimulate more advanced learning methods.

With the availability of online education content, Illich's learning webs could also support Morgan's statement regarding the shift from knowledge worker to learning worker. Upon entering the learning worker period in the $21^{\text {st }}$ century, what someone knows and how someone learns becomes less important. Learning workers challenge rigid institutionalised learning mechanisms where learning should follow restricted bureaucratic procedures in order to proceed. Institutionalised learning also has a strong correlation with apprenticeships, which presumes that someone can only learn specific knowledge from experts. In the learning worker era, this becomes more irrelevant as an individual's capacity and capability become harder to identify. Learning workers can learn and adopt anything quickly. Therefore, institutionalised education's hegemony has decreased following the flexibility and accessibility of learning.

Lastly, we would like to add another important point of learning webs that realistically occurs in today's trends of open science. Although dominantly provided with the help of ICT, open science does not have to be in a digital format. The digital educational platforms previously discussed are what Benedikt and Frieske call science 2.0, which is also part of open science (Fecher \& Friesik 2014). Thus, we can say that open science could also be conducted in conventional ways through local and community initiatives in order to organise the learning environment. To conclude, this sub-section has provided an argument about the possibility of open science which is correlated with Illich's learning webs. In the future, learning webs might significantly challenge the institutionalised education presence, and the question now lies on how to provide recognition for individuals that have accomplished their learning process in an informal and non-formal circumstances.

\section{Indonesia's schooling picture}

The Education for All (EFA) global monitoring report in 2015 highlighted relatively mixed achievements in the trend of providing education services (UNESCO 2015). Within nearly fifteen years of its implementation, EFA's commitment positively increased the global percentage of primary and lower secondary education enrolment rate. In 2015, the primary school net ratio was estimated to be $93 \%$, a $9 \%$ increase from $84 \%$ in 1999 . The positive trend also occurred in the lower secondary level, where between 1999 and 2012 there was a 14\% increase of lower secondary enrolment $(71 \%$ to $85 \%$ respectively). However, while the accomplishment looked quite impressive, the report pointed there was still a high number of out-of-school individuals and school incompletion.

Similar to EFA's achievement, Indonesia has accomplished an impressive expansion of the enrolment rate at all educational levels within the last two decades, despite still having a relatively high number of out-of-school groups (OECD \& ADB, 2015). The Ministry of Education and Culture released data stating that during 2016/2017 academic year, net primary enrolment at the national level reached 93.7\% (Kementerian Pendidikan dan Kebudayaan \& Pusat Data dan Statistik Pendidikan dan Kebudayaan, 2017). The percentage was smaller at the higher levels, including lower secondary (76.2\%) and upper secondary (61.2\%). From these figures of enrolment, there was also a small percentage of students who eventually dropped out at all levels; primary $(0.15 \%)$, lower secondary $(0.39 \%)$, and upper secondary (0.84). However, those who had never entered school were excluded from the statistics, emphasising the greater number of unschooled children and adolescents in the country.

The lack of financial capabilities became the most challenging burden that the families faced in order to keep their children enrolled in school. OECD and ADB (2015) illustrated that children from the lowest per capita expenditure families were likely to be the most vulnerable and experience more dropouts compared to children from the wealthiest families. As out-of-school children have few variations on their individual condition, this report also noticed that the total dropout rate was 
moderately low during the students' time at primary level. However, the rate tended to increase by the time the students entered secondary level.

Economic barriers were not the only challenging problem faced while delivering education in Indonesia. Consisting of more than 17,000 islands across the archipelago, geographical problems such as the distance to school and any disabilities remain the major causes of the out-of-school rate. Looking at the annual statistics regularly released by the Ministry of Education and Culture, the unequal distribution of education access had always occurred between urban and rural inhabitants (Suharti 2013). In fact, the years spent in schooling were higher for those living in urban areas than rural regions, despite the willingness of the government to allocate $20 \%$ of its national budget to education. Suharti found that the urban population spent 9.27 years in school while those living in rural areas only spent 6.54 years on average in 2010, compared to a 3.21-year gap in 1993. Thus, the progress of universal basic education in Indonesia might not have been equitably distributed, especially in an environment where education access that is of high quality is often inadequate or unavailable.

Education has been a crucial issue in Indonesia, since the country is predicted to gain demographic dividends in 2030. In 2030, the productive age group will reach $60.7 \%$ of the whole population (McKinsey Global Institute 2012). With the increase of the potential productive age supply, a call to provide quality education becomes a crucial issue in order to produce qualified, skilled workers, especially those possessing the relevant skills needed in the 21 st-century job market. Hence, education holds an essential role in the country's long-term economic growth plan. Strategies to provide educational services should be able to not only to expand the educational provisions, but also to promote social inclusion and geographical equity across the archipelago in the most possible, efficient, and effective way.

Achieving education for all in Indonesia will require sustainable and consistent commitment. Although today's government is concerned about improving infrastructure development in underdeveloped regions, the allocation resources needed will not be accomplished in a short period of time. Meanwhile, providing education service cannot be postponed. Education stakeholders, consisting not only of the education department, but also non-profit organisations and civil society, need to consider all available options to ensure the progress of the learning environment, especially for uneducated and out-of-school groups.

\section{Recognising deschooling initiatives: Best practices in Indonesia}

In the final years of EFA, the World Bank released a report entitled 'Learning for All: Investing in People's Knowledge and Skills to Promote Development' in 2011 to address any possible alternative education that can be done due to the unfinished business of school establishment. Despite its acknowledgment of upward trends towards school enrolment, the bank addressed more attention to learning as an ultimate education goals rather than schooling, both in and out of school (World Bank Group 2011). As the globe has recognised rapid changes in the $21^{\text {st }}$-century job market, technology development, and environmental degradation, education should be directed to answer today's challenges and to acquire the knowledge and skills needed in the future. We conclude that the international organisation has called for the recognition of any innovative education alternatives outside of school/formal education. Below is highlighted three case studies of deschooling initiatives in Indonesia in the form of informal learning, non-formal learning, and e-learning.

\section{Informal learning (Sokola Rimba)}

Sokola Rimba (in English, Jungle School) was firstly initiated by Butet Manurung, an Indonesian anthropologist who organised alternative education for the indigenous community. The children of indigenous communities normally do not enrol in formal education because of their nomadic lifestyle, the cost of education, and more importantly, the distance to the nearest school (Manurung 2013).

In its first years, Sokola Rimba taught mainly basic literacy such as reading and writing to children 
or adults who were curious, wanting to know what their children did. Instead of teaching in indoor rooms, Manurung and her colleagues deliver their lessons in any available space in the forest. Teaching tools were made of natural items such as wood sticks, sands, leaves, with only a few conventional "civilised" tools such as a blackboard and chalks due to the limited access to electricity, infrastructure, and adequate housing. Sokola implemented a learning process without having a restricted duration of time involved. Class began when the children became interested and ended whenever they wanted to stop or felt bored, because there was no such thing as study hours. We argue that Sokola Rimba's flexibility, inclusiveness, and adaptability are similar to the aspects of informal education as previously defined by Werquin (2011).

As the time goes by, Sokola finally realised that basic literacy was not adequate enough to solve the indigenous tribes' problems. Indigenous tribes have regularly faced a wide range of challenges that endanger their existence. These challenges include illegal logging, blast fishing, and other forestry exploitation that is highly influenced by market expansion. When the power of capitalism has entered their territory, their business interests often result in environmental destruction. Unfortunately, this is something that cannot be prevented by a tribe who is largely illiterate. To respond to this, Sokola has changed its perspective of learning method over the last few years. Learning methods should not only assist the students in mastering basic literacy, but also be concerned about problem-solving skills and self-awareness among both individuals and groups.

Once the indigenous community is equipped with adequate literacy skills, Sokola Rimba then advocates "the outside world". This is knowledge needed by the tribes, especially for recognising the interest of logging actors and traders coming to their area and when fighting for their ethnic rights. It is interesting to note that sokola rimba does not intend to motivate their students to be 'modern citizens'. Instead, the goal of Sokola Rimba is to provide a "life-teaching class" approach in order to enable the community to pursuing their purpose, whatever said purpose is. Thus, Sokola Rimba as a method of informal learning can offer a community-based needs learning circumstance depending on the challenges faced by the people. Based on Sokola Rimba's experience, trust building is urgent and necessary to convince a disadvantaged community that lessons should be organised in the first place.

In comparison with standardised education, sokola rimba is an initiative that pays more attention to individuals, and is not solely related to the job market. Informal education such sokola rimba is more about trying to connect and listen to what is important for the learners as human beings. This is something difficult to do in a school that is often targeted by restricted and non-flexible curriculums, exams, and job opportunities. According to Robinson and Aronica, when humans are valued, they start to give back and also expect to be valued (Robinson \& Aronica 2015). While the teacher is under pressure to achieve expected exam scores in his/her class, they will likely ignore the essential need to understand individuals as human beings and eventually forget what the essence of education is. From Sokola Rimba's case, we reflect that deschooling in the form of Sokola Rimba offers not only flexible but also organic (considering it is organised in an open space) driven learning which is not merely for economic reasons.

\section{Non-formal learning (Pesantren and Kampung Inggris)}

The next deschooling initiative is non-formal learning. Although similar to informal learning, nonformal learning offers a less-structured curriculum but not a completely free learning environment compared to the "learning as you like" implemented in Sokola Rimba. Both deschooling types are now recognised by worldwide organisations such as OECD (2011). The teachers are not necessarily equipped with formal degrees in the relevant field. They are often recognised by their competencies that enable them to transfer knowledge and skills to their disciples. Consequently, the learning circumstances in non-formal learning do not always follow the national curriculum, pedagogy and/or syllabus, pointing to its flexibility and personalisation depending on the learners' needs. Non-formal learning exists due to economic situations that offer a learning environment that is likely to be more affordable to low-economic groups. This is a confirmation that some non-formal learning has a profit motivation. However, non-formal learning offers a reasonable opportunity cost to their prospective 
students. In this study, we have recognised two non-formal learning methods that are well-illustrated in the form of Pesantren and Kampung Inggris.

Pesantren is an educational Islamic institutions which advocates the spread of Islamic religious teachings and has been recognised ever since the introduction of Islam in Indonesia. To this day, Pesantren has evolved from an educational institution into the biggest authentic Indonesian education system with a strong hold in the heart of the community. Compared to other formal educational institutions, Pesantren provides a unique learning environment. In Pesantren, all students or santri live together with their teacher or kyai in one residence. As a result, such a communal learning environment might help santri to develop a self-dependent capacity and the other important life skills that they need in order to survive.

Another interesting example is Kampung Inggris (English Village). Kampung Inggris is a neighbourhood located in Pare where its locals modify their houses to host non-formal English courses. These houses do not only become classes in the afternoon, but also boarding houses at night that function as student accommodation. Meanwhile, the teachers can be locals or newcomers who are equipped with an adequate English proficiency. They do not always have a teaching or English certification, as long they are able to teach. Geographically, Pare is far from big cities in the East Java region, making it harder for students to participate without staying in the village. This what makes Kampung Inggris distinctive from other courses in the big cities. As the students are accommodated by the locals, it is possible for the teachers to conduct a 24-hour learning environment as illustrated in the locals' rules related to implementing speaking English at any time as a policy, inside and outside of classes. Previous studies argue that this 24-hour learning environment is what stimulates the students to learn faster (Heningtyas et al. 2015, Karmala et al. 2018). In addition, each house offers a range of courses for students to enrol on based on what they need. For instance, there is a course that specialises in basic English skills, professional English skills and English testing mastery. Therefore, Kampung Inggris's visitors are facilitated not only by the flexible and effective learning environment, but also provided options related to their personal and interest-driven preferences.

\section{E-learning (Buku Sekolah Digital and IndonesiaX)}

The $21^{\text {st }}$ century is associated with the internet, information and communication technology. The existence of technology that enables interconnectivity between devices at the same time also allows us to develop the education system delivery further. Technology utilisation in the form of e-learning platforms is what we argue as being the invention closest to Illich's imagination regarding learningwebs. There are two forms of e-learning that we will address; open education resources (OER) and massive online open courses (MOOC).

An OER is an online repository that consists of digital materials that are accessible and unrestrictedly open to everyone. Learners, irrespective of their backgrounds, locations and conditions, are facilitated to provide educational materials through internet access (Perez 2017, Pierce 2016). In addition, what makes OER particularly distinguished is the 'openness' principle. Openness in OER is associated with a copyleft license, enabling its contents to be legally reused, redistributed, and recopied. Another striking advantage of OER is its ability to stimulate personalisation in learning. In schools where a formal curriculum is adopted, students are often constrained by a structured study pathway that limits their curiosity, creativity and flexibility in learning. It is commonly known that students are forced to attend classes or lessons that they are not interested in. This circumstance will not only increase the students' curriculum load, but also harden teachers, parents, and even themselves to find their real passion and interests. With the help of OER, students and learners are eased into exploring their talents by having educational contents available on their devices without worrying about the cost. However, realising the broader use of OER requires three core prerequisites; available technology, an accessible internet connection, and computer literacy.

In Indonesia, we have identified an initiative school called Buku Sekolah Digital (Digital Educational Books, hereafter BSD), which is an OER in the form of a digital library that was initiated by the 
partnership between NGOs and the Ministry of Education and Culture. BSD provides a wide range of books, mostly for primary and secondary level students. All of the books designed, published, and uploaded are under the license of the Ministry of Education and Culture and therefore make them legal to use and distribute. With the existence of BSD, it is hoped that the education paradigm that is identic with a high cost of distribution will be challenged by the materials that are available freely anywhere and at any time.

Another common ICT-based online education initiative is that of massive open online course (MOOC). MOOC is a distance-learning platform that enables learners to participate in a structured learning programme depending on the individual's needs (Mayer-Schönberger \& Cukier 2017, Perna et al. 2014)this study advances knowledge by considering two definitions of massive open online course (MOOC. MOOC was invented to upgrade the accessibility of normal classes, which is often associated with limited enrolments. The word 'massive' itself determines the unlimited number of seats in a digital class that has no restriction in relation to place and time. This means that the number of students enrolled in a particular class could be huge. In addition, similar to OER, learners are given the freedom to choose what courses they have an interest in. Despite many studies that have found it to have a low success rate related to completion (Macdonald \& Ahern 2015, Russell 2014), MOOC has been proven to be a promising initiative to increase accessibility, inclusivity and the flexibility of learning regardless.

An example of a significant MOOC initiative in Indonesia is IndonesiaX. IndonesiaX is a platform that provides academic and non-academic courses delivered by experts, including professionals and lecturers, on a wide range of topics. Over the last few years, Indonesia X has established a partnership with 20 institutions and organisations across the country. Besides implementing the characteristics of MOOC, IndonesiaX is also equipped with a learning management system (LMS), which is a feature enables the learners to track their progress and to provide feedback on the course organisers. While some of the services in Indonesia $X$ are mostly free of cost, the platform still enables the platform to obtain a profit by providing a certificate of accomplishment for those who complete the lessons. With Indonesia $X$ and other MOOCs, learners do not necessarily have to enrol with particular institutions to obtain lectures and lessons from the experts. Its open access assists in providing inclusive distancelearning for an unlimited number of learners in the country.

\section{Reflection: Why deschooling?}

We have interpreted and pointed out that the problem of universal schooling is based on the concept of equality. Institutional schools were meant to give everybody an equal chance in the job market. Unfortunately, schooling is frequently run without considering a person's barriers and obstacles. To challenge school hegemony, we need to address the concept of equality by Saunders. Saunders (1989) divided equality into three different categories: formal legal, opportunity, and outcome. Firstly, formal and legal equality emphasises that all men and women should be treated in the same way under the law. From Illich's perspective, universal law was meant to provide everyone with the same opportunity to keep learning, regardless of his/her social or economic status, area of living, and ability. Saunders secondly stated that equality means that the same opportunity should be given to individuals related to achieving equal chances to develop their potential. However, being giving the same opportunity does not mean that everyone will be guaranteed to end up with the same merits.

The critique of equality has been explained further by Thompson (2011). Equality does not merely mean equal; it can also be interpreted as different treatment depending on each person's condition (Thompson 2011:4). For instance, facilities in a building should consider access for disabled persons as they need special entrances. This special treatment is different from discrimination, which adheres to social patterns in terms of race, religion, class and gender via negative interpretations. What Thompson and Saunders referred to was promoting equity that is meant to give support and counteractive assistance to tackle barriers and obstacles that a person may meet in his/her unbalanced circumstances, leading to unjust treatment. The concept of equity is completely contradictory to institutionalised learning, where the certification mostly acknowledges the acquisition of proportional knowledge. 
Illich strongly criticised the misleading common understanding of schooling, where the majority of people believe the students always obtain the relevant lessons in preparation for their future. In fact, the school system and curriculum could be considered as a constraint for students seeking to reach their full potential. Illich saw that the way that a person absorbs knowledge is highly dependent on the intentional learning process, as the learning process does not necessarily need to be conducted in a strict environment. Unlike schools which embrace rigid teaching and certificates of learning recognition, deschooling pays more attention to human curiosity and the social environment. The deschooling idea offers students a more personalised, flexible, creative and interactive learning circumstance based on their pre-existing knowledge, learning preferences, needs, and goals without being wholly controlled by technocrats. In such an environment, students have a more positive learning experience because their learning attributes are tailored to them. Interest-based learning enables the students to determine their own educational pathway and they have the opportunity to learn based on their own learning pace. Thus, students can accomplish mastery at their own pace and take ownership of their learning.

Universal schooling detaches role assignment from personal life history in the standardisation. Robinson \& Aronica (2015:77) distinguished the burden in schools as being more concerned with proportional knowledge. It is undoubtedly true that academic skills are essential to measure a person's understanding of theoretical analysis, concepts, procedures, assumptions and hypothesis in particular knowledge construction. However, such concepts are not sufficient for acquiring life skills. Robinson and Aronica challenged the assumption that says that 'real intelligence is what you use in academic studies'. They supported the idea that humans learn casually and differently. Therefore, it is normal to see some children do well in schools while there are some who do not. Another striking point is related to Russel's thoughts. Compulsion in the education system enforces the students to pursue 'correctness' instead of exploring their natural curiosity, self-expression, and interest in aesthetic life (Russel 1977). Of course, the value of 'good' or 'bad' is something that should not be contradictory with what incumbent political leaders embrace, making knowledge more subjectively delivered as it will lead to a state monopoly on educational content.

Illich has inspired us; everyone can learn whatever, whenever, and with whoever they want. His proposal regarding learning web might have been impossible in his time, but now the internet has exists, it creates the possibility that education for all can be achieved by all. In spite of the fact that the advancement of information and communication technology does provide the possibility of deschooling society, the opportunities for deschooling cannot be restricted to mere technological feasibility. In contrast with schools, deschooling does not rely on the availability of physical infrastructure such as school buildings or classrooms. The learning process can occur in a wide variety of forms and take place at anytime and anywhere in an adjustable environment. Furthermore, deschooling, unlike schools, does not require certain qualifications for students to be admitted. On that account, it can be said that deschooling aims to achieve what Education for All has relentlessly fought for by promoting flexibility and inclusivity in the learning process.

Connected to today's challenges, the studying model in deschooling is not far from the transformation of the 'knowledge worker' (an outcome of institutionalised learning) to 'learning worker' (an outcome of unstructured but liberated learning) in today's internet of things era (Morgan 2016). Knowledge workers might possess a set of specific skills but they might have difficulty in facing a new and completely different circumstance. On the other hand, learning workers could easily adapt to a changing workplace environment since they are used to learning in a wide range of situations. Instead of focusing on 'what to learn', they put greater emphasis on 'how to learn'. Learning workers own the particular skills of adapting, learning and applying their learning to new situations. Such skills would eventually help them to deal with complex problems in the workplace.

As a matter of fact, companies are always looking for a candidate who has the appropriate skills and experience required to do the job properly. Interestingly, there are numerous companies like Google, 
Apple, and IBM which no longer require a formal educational degree as their selection method for some positions. When it comes to assessing candidates, academic qualifications could act as a barrier to those who do not have a formal degree, whilst many talented applicants might gain their skills outside of a traditional academic institution. In addition, the existing formal education institutions do not seem to produce graduates with the sufficient knowledge, skills, and competences required by the labour market. Therefore, there should be a method for recognising non-formal and informal learning outcomes. Even though the recognition of non-formal and informal learning outcomes does not necessarily call for a formalised arrangement, the most widespread method used by many countries is the use of a learning portfolio (Werquin, 2011). Through the learning portfolio, people can freely show or even demonstrate their capacities and capabilities in any possible ways, shapes, and forms.

\section{Possible challenges}

Although offering a flexible, open, and personalised learning circumstance, it is undeniable that deschooling might confront challenges that possibly hinder its implementation and outcomes. We have predicted some of the noticeable challenges.

\section{The limitation of self-directed learning}

The idea of deschooling would enable everyone to use the self-directed learning method as a tool for learning. Self-directed learning is a learning method in which individuals become their own learning agent by taking the initiative when diagnosing their learning needs, conducting a learning need assessment, planning their learning objectives, identifying relevant sources and applying appropriate learning strategies (Knowles 1975). Whilst self-directed learning may have a number of advantages, its shortcomings cannot be overlooked. According to a recent study, self-directed learning is not an effective learning tool for all students (Bhat, Rajashekar, \& Kamath 2007). This study demonstrates that self-directed learning could benefit some students to understand concepts but other students lacking the requisite cognitive skills might suffer. These cognitive skills include the ability to gather and process information, as information overload is a common problem faced by self-directed learners. Thus, the challenge is to create a systematic design in the self-directed learning process which can accommodate 'weaker' people.

\section{The pitfall of institutionalised capital}

The idea of deschooling will remain a mere potential if institutionalised capital in the form of educational degree certifications are valued more than the knowledge and skills acquired in other alternative methods (Bourdieu 1986). On this basis, it is obvious that wide social change is necessary in order to take a step further toward Illich's deschooling society. The government and corporations should be jointly involved in determining the competencies required for a particular profession or occupation. The industry-aligned and competency-based approach is essential to ensure that what individuals learn is in parallel with the knowledge and skills that they will need in order to do their job properly.

\section{The lack of social interaction}

The development of information and communication technology, in general, provides an adequate technical infrastructure for Illich's educational network. The use of technology enables the delivery of education to become more accessible. This is in accordance with Illich's principles. In addition, digital learning has immense opportunities compared to conventional education in schools. However, it also has some major drawbacks in spite of its benefits. One of the greatest concerns regarding digital learning has always been a lack of social skills. The absence of physical and face-to-face interaction with peers may hinder the development of social competence (Shoaf 2007). The ability to master social skills requires practice and interaction. On the other hand, the importance of developing such skills is significant in life as it will help them to survive in society (Gresham, Bao \& Cook 2006). 


\section{Conclusion}

The struggle to achieve Education for All still involves a long and winding road from what we have achieved today. Despite being allocated with an enormous budget, the mass spread of school establishments has led to a wider social gap in society which is fully controlled by dominant central technocrats. Institutionalism has unintentionally shifted the hegemony that "education is about schooling'. The idea of deschooling by Illich has inspired and remained debated by scholars, challenging the commercialisation in education which has enormously eliminated disadvantaged groups who are being left behind more than ever before. The study of education for all has enlightened scholars, stating that promoting equality does not mean necessarily giving the same equal chance to everybody, as it may result in the same equitable outcomes. Scholars have encouraged us that everyone was born differently and should not be compared in the same standardisation structure.

Although alternative learning methods might not improve the statistical records on education delivery, we argue that these activities urgently need to be delivered. As most countries with a high number of out-of-school individuals are highly dependent on infrastructure, school facilities, and legal alternatives, it is doubtful that the goal to provide basic education for all could be done in the near future. Learning activities for disadvantaged and marginalised individuals must keep running. Three case studies of deschooling initiatives in Indonesia shows that deschooling society is certainly feasible. A pivotal principle that can be highlighted through the use of digital technology in deschooling is the right to use, copy, and modify learning materials freely. The realisation of deschooling can enable liberation in the learning process, where everyone can learn anything, anywhere and at any time, with whomever he or she wants. As there is a lack of recognition of learning outcomes acquired outside of formal educational institutions, those without academic degrees eventually look for other possible ways to show what they are capable of, allowing them to think outside of the box. However, the potential challenges of deschooling, such as the limitation of self-directed learning, the lack of social interaction and the pitfall of institutionalised capital, should also be taken into consideration.

\section{References}

Apple M (2012) Analyzing Hegemony. Knowledge, Power, and Education: The Selected Works of Michael W. Apple. New York: Routledge. 30-51.

Bartling S \& Friesike S (2014) Opening Science the Evolving Guide on How the Internet is Changing Research, Collaboration and Scholarly Publishing. London: Springer Cham.

Bhat PP, Rajashekar B \& Kamath U (2007) Perspectives on self-directed learning - The importance of attitudes and skills. Bioscience Education 10 (1):1-3.

Bourdieu P (1986) The Forms of Capital. Handbook of Theory and Research for the Sociology of Education. New York: Greenwood Press. 241-258.

Fairclough N (2003) Analysing Discourse: Textual Analysis for Social Research. London: Routledge.

Fecher B \& Friesike S (2014) Open Science: One Term, Five Schools of Thought. In: S Bartling \& S Friesike (eds). Opening Science The Evolving Guide on How the Internet is Changing Research, Collaboration and Scholarly Publishing. Amsterdam: Springer. 17-47.

Fraser N (2000) Rethinking recognition. New Left Review 3 (3):107-118, 107-120.

Heningtyas MA, Sjamsuddin S \& Hadi M (2015) Peran pemerintah dan masyarakat dalam upaya pengembangan pendidikan non-formal (Studi kasus: Eksistensi "Kampung Inggris" Kabupaten Kediri ). Jurnal Administrasi Publik 2 (2):264-268.

Illich I (1971) Deschooling Society. New York: Harper \& Row.

Karmala ET, Kristina D \& Supriyadi S (2018). Learning Public Speaking Skills from An Ethnography Study of "Kampung Inggris." In: English Language and Literature International Conference.

Kementerian Pendidikan dan Kebudayaan \& Pusat Data dan Statistik Pendidikan dan Kebudayaan (2017) APK dan APM PAUD, SD, SMP, dan SM (termasuk Madrasah dan sederajat) Tahun 2016/2017. Report dated January 2017. 
Knowles M (1975) Self-directed learning: A guide for learners and teachers. Group \& Organization Studies 2 (2):256-257.

Kominek J (2009) Linking Institutionalism and Path Dependency Theory. University of Hamburg, Research Group Climate Change and Security.

Gresham FM, Bao M \& Cook C (2006) Social skills training for teaching replacement behaviors: Remediating acquisition deficits in at-risk students. Behavioral Disorders 31 (4):363-377.

Macdonald P \& Ahern TC (2015) Exploring the instructional value and worth of a MOOC. Journal of Educational Computing Research 52 (4):496-513.

Manurung B (2013) Sokola Rimba. Buku Kompas.

Mayer-Schönberger V \& Cukier K (2017) Big Data - The Essential Guide to Work, Life, and Learning in the Age of Insight. London: John Murray Publisher.

McKinsey Global Institute (2012) The Archipelago Economy: Unleashing Indonesia's Potential. Report dated September 2012.

Morgan J (2016) Say Goodbye totrange Legacy of Ivan Illi Knowledge Workers and Welcome to Learning Workers. https://www.forbes.com/sites/jacobmorgan/2016/06/07/say-goodbye-toknowledge-workers-and-welcome-to-learning-workers/\#3f6efb642f93.

OECD \& ADB (2015) Education in Indonesia: Rising to the Challenge. Report dated March 2015.

Perez J E (2017) Images and the Open Educational Resources (OER) movement. Reference Librarian 58 (4):229-237.

Perna LW, Ruby A, Boruch RF, Wang N, Scull J, Ahmad S \& Evans C (2014) Moving through MOOCs: Understanding the progression of users in massive open online courses. Educational Researcher 43 (9):421-432.

Pierce M (2016) Looking at OER with a critical eye: Strengthening OER initiatives by focusing on student learning. Community and Junior College Libraries 22 (1-2):11-17.

Robinson K \& Aronica L (2015) Creative Schools: Revolutionizing Education from the Ground Up. New York: Allen Lane.

Routray S (2012) "Deschooling Society": The Sch. Contemporary Education Dialogue 9 (1):85-104.

Russel B (1977) Education and the Social Order. London: Unwin Paperbacks.

Russell A (2014) Research resource review: Introduction to sustainability - a massive open online course (MOOC). Progress in Physical Geography 38 (6):827-829.

Saunders P (1989) The question of equality. Social Studies Review 5 (2):77-82.

Schofer E \& Meyer JW (2005) The worldwide expansion of higher education in the twentieth century. American Sociological Review 70 (6):898-920.

Shoaf LM (2007) Perceived advantages and disadvantages of an online charter school. American Journal of Distance Education 21 (4):185-198.

Suharti (2013) Trends in Education in Indonesia. Education in Indonesia. 15-53.

Thompson N (2011) Promoting Equality. London: Palgrave Macmillan.

UNESCO (2014) Teaching and Learning Achieving: Quality for All. Education for All Global Monitoring Report 2013-2014.

UNESCO (2015) Education For All 2000-2015: Achievements and Challenges. EFA Global Monitoring Report.

Werquin P (2011) Recognition of Non-Formal and Informal Learning: Country Practices. Report dated February 2010. OECD.

World Bank Group (2011) Learning for All: Investing in People's Knowledge and Skills to Promote Development. Report dated August 2011.

Zaldívar J I (2015) Deschooling for all? The thought of Ivan Illich in the era of education (and learning) for all. Foro de Educación 13 (18):93-109. 